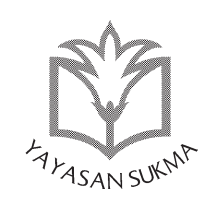

SUKMA: JURNAL PENDIDIKAN

ISSN: 2548-5105 (p), 2597-9590 (e)

Volume 2 Issue 2, Jul-Dec 2018, pp. 205-222

https://doi.org/10.32533/02203.2018

www.jurnalsukma.org

\title{
AGAMA DALAM BONEKA \\ Globalisasi dan Wajah Baru Orang Tua dalam Pendidikan Islam
}

\section{Milda Amalia}

UIN Sunan Kalijaga Yogyakarta, Indonesia

mildaamalia17@gmail.com

\section{Abstrak}

Globalisasi telah mengubah cara pandang orang dalam menghadapi berbagai hal, termasuk dalam hal pendidikan Islam. Perubahan itu dialami oleh para orang tua yang memiliki anak dalam masa pertumbuhan dan perkembangan. Hadirnya boneka islami -studi kasus boneka Hafiz- di Indonesia ternyata mempengaruhi pemaknaan tersebut. Boneka islami yang bisa disebut sebagai virtual religion mampu memprivatisasi pendidikan agama Islam pada anak-anak mereka. Tulisan ini ingin mencoba menemukan bagaimana pemaknaan pendidikan Islam bagi orang tua yang telah mengon- 
sumsi boneka islami tersebut dan atau bahkan hingga terjadi suatu komodifikasi pendidikan agama Islam. Globalisasi telah melintasi batas pasar dengan bukti hadirnya boneka tersebut sebagai peluang komoditi agama. Hal ini disebabkan harga boneka yang tidak murah, dan market mereka bisa dikatakan melebihi target. Di mana boneka yang dilihat dari segi harga dan kualitas diperuntukkan bagi kalangan kelas atas, namun peminat lebih banyak terletak pada orang tua kelas menengah.

Kata kunci: globalisasi, boneka islami, komodifikasi, pendidikan Islam, orang tua.

\section{A. Pendahuluan}

Ketika praktik-praktik agama yang semula menjadi hal yang sakral, namun hadirnya era Globalisasi memberikan pemaknaan yang tidak bisa dijadikan sebagai acuan yang pasti. Tidak mampu lagi manusia membedakan agama mana yang profan dan sakral, mana yang tidak dalam dan dangkal, karena semua hadir dalam ruang yang campur aduk, tidak hanya dalam budaya, hiburan, pendidikan bahkan nilai-nilainya dan agama pun mengalami komodifikasi.

Di era global seperti ini tidak ada salahnya perlu kecemasan tentang generasi milenial yang mana dipercaya sebagai penentu hasil ke depan peradaban bangsa. Berkembangnya agama melalui media sosial, media online hal ini memunculkan "agama baru" ritual-ritual agama Facebook, Google, Twitter dan sebagainya menjadi tempat yang bebas dan nyaman mengembangkan imajinasi dan kreasi mereka. Mulai cyber religion di era internet sudah banyak yang mengulasnya, di mana agama online menjadi konsumsi publik dan manusia tidak lagi kekurangan informasi namun kebanjiran info tentang agama itulah yang menjadikan manusia terjebak dalam menyaring info dan ajaranajaran tentang agama. Era post-truth inilah kelenaan manusia 
diuji menuju pada kecerdasan dalam bermedia sosial, media internet dan semacamnya.

Kajian-kajian tentang ritual-ritual virtual telah banyak diulas. Saat ini yang cenderung baru dan hadir di Indonesia bukan lagi agama melalui online, namun merambah objek anakanak melalui media boneka. Pemilihan boneka bisa jadi bahwa ia adalah mainan tidak ada matinya selalu menjadi mainan favorit anak-anak. Boneka didesain dengan bentuk dan simbol anak saleh, di dalamnya terdapat konten-konten islami, seperti murattal Al-Quran, doa-doa, bahkan yang mampu mentransformasikan berbagai ilmu pendidikan religius kepada anak menjadi pilihan yang diserbu oleh para orang tua. Orang tua -baru- ini lebih banyak meminati mainan tersebut dengan imagine in world order anak-anaknya menjadi saleh. Keinginan orang tua menjadikan anaknya saleh menjadi motif tersendiri. Walaupun mengonsumsi mainan tersebut belum menjamin kesalehannya. Media ini merupakan masuk dalam kategori virtual religion namun berbasis offline.

Bentuk dari hadirnya media-media yang membentuk sebagai Islam virtual ini juga seirama dengan munculnya Islam populer. Menurut Wasisto, "Islam Populer" merupakan bentuk pengaruh modernisasi terhadap nilai-nilai budaya Islam dalam masyarakat. Akulturasi tersebut kemudian secara langsung maupun tidak langsung mengubah budaya Islam yang semula dipersepsikan sebagai budaya konservatif, kovensional, dan eksklusif menjadi lebih dinamis dan modernis. Ada berbagai contoh budaya Muslim populer tersebut mulai dari fashion, musik, gaya bahasa, maupun juga perilaku sehari-hari. Munculnya berbagai ragam produk Islam modern menunjukkan bahwa budaya Islam sebenarnya berjalan dinamis (Jati 2015). Sehingga untuk kasus media boneka ini menurut hemat penulis masuk dalam Islam populer karena dikonsumsi secara massal dan apakah boneka islami tersebut masih bisa dikatakan agama virtual, atau wajah baru orang tua di era global seperti ini. Di sisi lain agama dikomodifikasi dan mass production begitu nyata dalam produksi boneka tersebut. 


\section{B. Pasar Global Melintasi Batas}

Pasar bebas sebagaimana cita-cita global telah terwujud dengan salah satu datangnya MEA (Masyarakat Ekonomi Asean). Hubungan perdagangan internasional semakin nyata. Ekonomi global memang tidak bisa dihindari dan harus dihadapi. Stiglitz (2003) memberikan resep untuk globalisasi yang lebih adil. Ia menjelaskan bahwa negara-negara maju harus membuka pasarnya bagi negara-negara miskin tanpa asas resiprokal (timbal balik). Pemerintah di negara miskin agar tidak melakukan liberalisasi terlalu cepat, tapi hendaknya secara bertahap menyesuaikan dengan kondisi masing-masing negara. Bahkan ia menekankan jika setiap negara tidak terlalu menggantungkan pada Amerika (Stiglitz 2006). Resep ini perlu diterapkan oleh negara-negara sedang berkembang seperti Indonesia. Perlunya memikirkan kondisi negara sendiri menjadi fokus utama, tidak perlu melampaui dan keinginan untuk mempercepat menuju ekonomi liberal.

Pasar global erat kaitannya dengan perdagangan, dalam analisa Martin Wolf ialah asumsi bahwa pergerakan modal dan buruh dicegah. Suatu negara memiliki kumpulan buruh, modal, dan tanah yang terbatas. Alasan mengadakan perdagangan ialah untuk meningkatkan peluang bagi pemilik faktor-faktor produksi untuk terlibat dalam transaksi yang menguntungkan (Wolf 2004, 96). Di Indonesia industri-industri telah masuk dengan sistem sales, jadi setiap orang tidak perlu memiliki modal hanya memperjualkan produk dagangan dan sales itu jika memiliki pencapaian tertinggi maka akan naik level. Sistem seperti ini juga diterapkan dalam perdagangan dalam maianan edukasi anak 'boneka hafiz' tersebut.

Adam Smith (1723-1790) mencetuskan pemikiran tentang kesejahteraan bangsa sangat tergantung oleh kebebasan pasar, dan ini menjadi dasar bagi kapitalisme yang mempercayai sepenuhnya pasar bebas. Individu bebas bertindak dalam rangka memenuhi kepentingan pribadi yang berdampak pada peningkatan kesejahteraan publik dibandingkan oleh pasar 
yang dikendalikan dan dimonopoli oleh negara (Smith 1976). Di sinilah sebab kelas menengah semakin meningkat secara signifikan dibandingkan dengan kelas menengah atas. Berpijak dari sini, pasar berani melintas batas ini telah dirasakan di Indonesia. Bahkan lintasan pasar global saat ini telah membidik kelas menengah muslim dengan melintasi 'pasar agama'. Agama menjadi modalutama dalam memasarkan produk-produkmuslim. Berdasarkan hasil survey bahwa kelas menengah memiliki daya konsumsi yang tinggi, hal ini dibuktikan pada hasil survey bahwa target market mereka mengalami signifikansi. Produk yang diperjualbelikan dengan berlabel agama, momen-momen islami menjadi target terpopuler bagi para kapital. Selain itu, produkproduk yang digunakan sehari-hari mulai dari makanan, sabun, pasta gigi, jilbab, sampai kosmetik berebut untuk mendapatkan label halal. Target market inilah pada kenyataannya memang diburu para muslim konsumer, sehingga mereka akan terlihat muslim jika telah mengonsumsi produk-produk halal tersebut. Berlomba berburu menjadi nasabah syariah, tren umrah berkalikali ini, semua ini tidak lepas dari pengaruh kapitalisme.

Pasar yang telah melintasi batas, yakni telah masuk pada ruang agama ini tidak luput dari bidikan trend saat ini ialah mereka menyebutkan 'mainan edukasi islami'. Artinya ini telah melampau batas posisi kedua yakni pada target anak-anak. Mainan edukasi islami yang dikemas dengan alat teknologi, keunikan modelnya, menjadi daya tarik para konsumer termasuk orangtua dan anak. Di awal disebut sebagai pasar agama ini tidak lain ialah agama yang terkomodifikasi. Kitiarsa komodifikasi agama merupakan konstruksi historis dan kultural yang kompleks, sekian demikian ciri komersial mereka begitu nyata. Mereka direproduksi dalam konteks kebudayaan tertentu dan kemudian mepersyaratkan kerangka kultural untuk mempertegas signifikasi simbolik sosioekonomi mereka. Komodifikasi merupakan sebuah proses yang benar-benar diciptakan dan disertakan dalam saluran ekonomi pasar lokal-global dan ledakan agama postmodern. Komodifikasi memang tidak bertujuan memproduksi bentuk dan gerakan agama baru berlawanan dengan keyakinan akan mendudukan 
agama sebagi barang yang melaluinya fungsi spiritual agama menjadi komoditas yang layak dikonsumsi dalam masyarakat (Kitiarsa 2008, 1).

Karl Marx mengawali 'kapital' dengan analisis tentang komoditas telah menjadi bentuk paling jelas, representasi paling eksplisit, dari produksi kapitalis. Kapitalisme secara harfiah "tampil" sebagai koleksi komoditas yang luar biasa besarnya. Salah satu kunci analisis Marxian adalah mendekonstrukasi komoditas untuk menentukan apa makna yang tampak, untuk membongkar relasi-relasi sosial yang membeku dalam bentuk komoditas. Bagi Marx, komoditas berasal dari rentang luas kebutuhan, baik fisik maupun budaya dan nilai gunanya dapat didefinisikan dalam berbagai cara (Marx 1976, 125). Namun, tidak semua berpandangan dengan Marx. Beberapa kritikus yang merasa tidak puas dengan formulasi Marx, berpendapat bahwa pembedaan antara nilai guna dan nilai tukar lebih mengaburkan ketimbang menjelaskan. Misalnya Marx mengakui karakter sosial semua nilai, tetapi cenderung untuk menturalisasikan nilai guna (Sahlins 1976, 15).

\section{Ada Agama dalam Boneka}

Di sini seakan menegaskan kembali bahwa agama saat ini tidak mampu lagi dipisahkan oleh media. Secara bersamaan, agama dan media telah saling berkelindan dalam pengalaman kultural khalayak media (Hoover 2006, 3). Media (film, radio, televisi, media cetak, elektronik, teknologi digital, dan sebagainya) mengambil lebih banyak peran, termasuk peran spiritual dan transenden yang pada awalnya hanya merupakan wilayah kerja agama. Hal ini berarti bahwa agama dan media kian mengalami konvergensi dan keduanya sama-sama berperan dalam kehidupan sehari-hari. Sedangkan Hjarvard dalam Morgan menegaskan bahwa secara umum kajian mengenai hubungan antara agama dan media dapat muncul dalam dua tradisi. Tradisi pertama lebih memfokuskan pada agama dalam media (religion in media), yakni yang mengkaji tentang bagaimana agama-agama besar seperti Protestan, Katolik, Islam dan agama-aga- 
ma lainnya serta teks-teks penting mereka direpresentasikan dalam media dan bagaimana pengaruhnya pada para penganutnya secara individu, institusi keagamaan dan dalam konteks yang lebih luas. Sementara tradisi yang kedua lebih banyak digunakan oleh kalangan culturalist yang lebih menitikberatkan pada pengkajian (Morgan 2008, 4-13).

Media sebagai agama (media as religion). Tradisi kedua ini, di satu sisi menggabungkan pemahaman yang lebih luas tentang agama sebagai praktik cultural meaning-making berhubungan dengan "things set apart" dengan pendekatan cultural studies pada media dan komunikasi di sisi lainnya. Semua ini berkonsekuensi pada fakta bahwa agama sebagai lembaga tidak lagi menjadi pusat perhatian, akan tetapi lebih difokuskan pada penerimaan audiens dan penggunaan media sebagai cara beragama. Dari perspektif ini, tidak ada lagi pembedaan antara agama dan media, sebab sebagaimana ditegaskan Hoover, agama dan media menempati ruang yang sama, melayani tujuan-tujuan yang sama dan memperkuat praktik-praktik yang sama (Hoover 2006, 9).

Jika perdebatan sebelumnya tentang hadirnya boneka-boneka muslim sebagai bentuk resistensi terhadap boneka 'kafir' yaitu pada Barbie seperti di Iran dan Saudi. Mereka semangat memproduksi boneka-boneka muslim dengan mode fashion islami -berjilbab, berjubah- bahkan sampai kulit boneka menyesuaikan negara tersebut (Dunn \& Dunn 2016). Seakan memang boneka Barbie digolongkan sebagai boneka "sekuler" sebagaimana disampaiakan oleh Budiyanto. Barbie sebagai komoditas global, populer dan diekpor ke berbagai negara Barat sehingga memebentuk budaya global tersendiri (Budiyanto 2009, 4).

Di Indonesia telah hadir produsen mainan di mana mereka memberinya nama 'mainan edukasi islami'. Salah satu produk andalan dan best seller ialah 'Hafiz Talking Doll' atau biasa disebut dengan boneka hafiz. Boneka ini didesain sepasang yakni boneka simbol anak laki-laki saleh atau dinamakan Hafiz dan simbol anak perempuan salehah bernama Hafizah. Kedua boneka ini bisa berbincang satu sama lain, bahkan boneka bisa berbicara dengan manusia ada pilihan tombol yang disediakan. Boneka ini 
memiliki ratusan konten islami, tepatnya memiliki 13 fitur 265 konten dilengkapi bilingual dan bisa terhubung dengan android. Konten itu diantaranya murottal 30 juz, doa harian, asmaul husna, cerita $25 \mathrm{Nabi}$, lagu-lagu islami. Dari konten dan fasilitas tersebut, para orang tua tergoda dan berbondong-bondong mengonsumsinya. Padahal jika dilihat dari segi bandrolnya sangat tidak murah. Di sinilah bisa menjadi nilai distingsi tersendiri bagi orang tua.

Boneka itu termasuk virtual religion (agama virtual) yang tidak bisa dielakan di era saat ini. Bahkan telah menjalar pada objek anak-anak. Ketika dahulu media belum secanggih saat ini, agama masuk dalam langganan sms, atau yang disebut dengan sms Tauhid. Menurut penelitian Fakhruroji (2014) bahwa Institusionalisasi SMS Tauhiid sebagai langkah internalisasi logika media berujung pada banalisasi tausiah sebagai praktik agama yang diindikasikan melalui percampuran konten agama dan nonagama. Dominasi logika media dalam SMS Tauhiid telah menyebabkan terjadinya komersialisasi dan komodifikasi agama. Komersialisasi ditandai keterlibatan SMS Tauhiid dalam ekonomi praktis yang mengindikasikan bahwa SMS Tauhiid tidak lagi hanya bertujuan untuk kepentingan religius tetapi juga ekonomi. Sementara itu praktik komodifikasi diindikasikan dari komodifikasi konten melalui 'penjualan' konten kepada operator dengan kompensasi keuntungan bagi pihak SMS Tauhiid. Komodifikasi khalayak ditandai dengan transformasi jamaah kepada khalayak konsumen melalui penggunaan database pelanggan untuk mendapatkan sponsor dari pihak-pihak operator seluler. Komodifikasi proses ditandai dengan upaya perluasan layanan melalui website, teknologi streaming dan jejaring sosial yang pada dasarnya dilakukan dengan tujuan untuk menggiring para pengunjung agar melakukan pendaftaran sebagai pelanggan SMS Tauhiid.

Di sisi tersebut agama memang seolah dijadikan sebagai sebuah komoditas, namun sisi lainnya memang media menjadi sesuatu yang membantu dalam mendapatkan pengetahuan-pengetahuan agama. Memang pilihan komoditas ini menjadi tidak relevan jika dikaitkan dengan agaman, namun di situlah fakta yang ada saat ini. Bahkan ternyata tidak hanya agama Islam saja yang telah menjadi komoditas, 
bahkan agama-agama lain pun tidak jauh dari hal tersebut. Misalnya praktik keagamaan Hindu. Hindu pada tingkat kehidupan sehari-hari membutuhkan rangkaian spesialis keagamaan dan perlengkapan ritual yang luar biasa. Pada tingkat praktik, Hindu kebaktian adalah agama yang diwujudkan dan didasarkan pada materialitas, yang membuat keberadaan benda fisik tertentu (yang bila digunakan dalam ibadah juga membawa beban ritual dan simbolis yang luar biasa) merupakan bagian tak terpisahkan dari praktik keagamaannya (Sinha 2011). Bahkan penelitian objeknya se-Asia tentang agama yang telah terkomodifikasi dengan target pasar kelas menengah telah terungkap (Kitiarsa 2008).

Jika dikalangan penelitian komunikasi, bahwa komodifikasi memiliki dua arti penting. Pertama, proses dan teknologi komunikasi telah berkontribusi pada proses umum komodifikasi dalam ekonomi secara keseluruhan. Misalnya, perbaikan saluran komunikasi dalam bisnis pakaian, teknologi canggih yang telah memperluas informasi mengenai seluruh sirkuit produksi, distribusi, dan konsumsi. Kedua, proses komodifikasi yang berjalan dalam masyrakat secara keseluruhan mempenetrasi proses komunikasi dan institusi, sehingga perbaikan dan kontradiksi dalam proses komodifikasi sosial mempengaruhi komuniasi sebagai suatu praktik sosial (Mosco 2009, 17).

Komodifikasi agama di Indonesia banyak dimanfaatkan melalaui acara televisi. Keluguan audiens inilah yang akhirnya dimanfaatkan oleh televisi komersial dengan menggelontorkan program-program religius yang menurut media audio visual itu digemari khalayak. Dapat diduga komoditas baru atas nama agama semakin banyak menghiasi layar kaca pemirsa setia televisi (Yusuf 2016,8). Pada akhirnya preferensi atas acara televisi kegemaran itu dikonversi menjadi rating dan dijual kepada pengiklan. Audiens yang sejatinya adalah pemilik sah frekuensi sekali lagi menjadi korban kekuatan kapitalisme media.

Secara umum ada lima tipe komodifikasi menurut Vincent Mosco (1996, 145-161) yaitu komodifikasi isi, komodifikasi khalayak, komodifikasi tenaga kerja, komodifikasi masa kanak- 
kanak dan komodifikasi nilai. Komodfikasi isi, menjadi pusat perhatian kajian ekonomi politik media dan komunikasi. Ketika pesan atau isi komunikasi diperlakukan sebagai komoditas, ekonomi politik cenderung memusatkan kajian pada konten media dan kurang pada khalayak media dan tenaga kerja yang terlibat dalam produksi media. Tekanan pada struktur dan konten media ini bisa dipahami terutama bila dilihat dari kepentingan perusahaan media global dan pertumbuhan dalam nilai konte media.

Kedua, komodifikasi khalayak. Ekonomi politik menaruh beberapa perhatian pada khalayak, khususnya dalam upaya untuk memahami praktik umum dengan cara pengiklan membayar untuk ukuran dan kualitas (kecenderungan untuk konsumsi) khalayak ang dapat diraih surat kabar, majalah, wesite, radio, atau program televisi.

Ketiga, komodifikasi tenaga kerja. Untuk mengkaji proses komodifikasi isi dan khalayak media, penting untuk mempertimbangkan komodifikasi tenaga kerja media. Tenaga pekerja komunikasi yang juga dikomodifikasi sebagai buruh upahan telah tumbuh secara signifikas dalam pasar kerja media. Dalam menghadapi komodifikasi ini, para pekerja media telah menanggapi dengan menggalang orang-oran dari media berbeda, termasuk jurnalis profesional penyiaran, dan spesialis teknis dalam film untuk bergabung dalam serikat pekerja dan organisasi-organisasi pekerja lain yang diklaim mempresentasikan segmen terbesar dari tenaga kerja komunikasi.

Keempat, komodifikasi masa kanak-kanak. Konsekuensi dari komodifikasi masa kanak-kanak ini telah menimbulkan gangguan atau disrupsi dalam kehidupan sehari-hari anak-anak yang mungkin mengambil berbagai bentuk perubahan penggunaan waktu dan pengacauan proses pertumbuhan anak. Oleh karena anak-anak dan masa kanak-kanak terus mengalami komodifikasi, maka tidak ada wilayah paling kontroversial, selain juga dunia perempuan, sehingga telah melahirkan sejumlah perdebatan hangat dalam kajian budaya dan media. Komodifi- 
kasi masa kanak-kanak ini juga dilakukan melalui konstruksi dunia bintang anak-anak oleh media di pentas hiburan tekevisi dan budaya populer.

Kelima, “Komodifkasi Nilai”. Komodifikasi nilai ini menjelma dalam proses komodifikasi yang menguat dalam dunia pendidikan dan agama. Graham Ward, seorang profesor etika dan teologi kontekstual di Universitas Manchester, telah menulis esai kritis "The Commodification of Religion, or The Consummation of Capitalism". Di dalam esainya, Ward menjelaskan bahwa Marx tidak menggunakan istilah komodifikasi, melainkan ia merujuk pada berbagai konsep yang digunakan Marx untuk mendeskripsikan pengalaman manusia mengenai nilai dibawah rezim baru kapitalisme.

Komodifikasi, selanjutnya, hampir berhubungan dengan reifikasi (Verdinglichung dalam istilah Marx). Seperti dijelaskan Ward, komodifikasi adalah apa yang terjadi dengan benda-benda dalam kapitalisme, sementara reifkasi adalah apa yang secara stimulant terjadi pada pribadi-pribadi (Ward 2005, 327). Pada hakikatnya, tidaklah wajar ketika benda-benda diubah menjadi suatu yang personal dan pribadi-pribadi diubah menjadi benda-benda. Namun memang saat ini bahkan semua agama telah terkomodifikasi dengan berbagai barang-barang. Dengan kata lain agama di sini bisa menjadi fetis. Ketaatan agama yang dipengaruhi oleh benda-benda, mempresentasikan sesuatu itu sendiri atau sebagai tanda.

\section{Imagine Orang Tua "Baru”}

Anak menjadi anugerah tak terhingga bagi orang tua. Orang tua "baru" yang memiliki anak akan merasakan dua sisi hak dan kewajiban, mereka berhak sangat bahagia dan kewajibannya menjadikan anak yang saleh. Terlepas makna saleh mereka didefinisikan seperti apa, yang pasti saleh di mata mereka ialah anak yang baik berbakti pada orang tua dan Tuhannya. Bahkan para orang tua muda yang belum memiliki banyak pengetahuan dan bahkan pengalaman dalam mendidik anak, maka mereka 
akan memilih jalan instan atau praktis. Imajin orang tua untuk memiliki anak yang saleh ternyata tidak cukup tanpa ada pendukung simbol-simbol agama. Hal ini ditunjukkan dengan semangat konsumsi para orang tua muda pada mainan edukasi islami -boneka hafiz- dianggap menjadi alternatif bagi kesalehan anak. Pemaknaan kesalehan tidak lagi menjadi sebuah nilainilai agama, akan tetapi menguatkan simbol-simbol agama. Ini yang menjadi problem nilai-nilai pendidikan agama. Kehadiran boneka itu seakan membantu para orang tua dalam mentransformasikan pengetahuan agama pada anak. Namun, inilah sisi yang terlewatkan oleh orang tua, di mana bahwa usia anak-anak justeru penekanan transfer of value yang seharusnya menjadi prioritas utama. Sebagaimana kata Bourdieu bahwa motivasi bawah sadar itu yang efektif, seperti teladan (Bourdieu 1977, 79). Teladan ini menjadi efektif bagi anak dalam menanamkan kebiasaan-kebiasaan baik sehingga akan menjadi habitus.

Perkembangan teknologi salah satu efek dari globalisasi, sehingga kecemasan akan masa depan anak-anak semakin meningkat. Era itu di mana ditunjukkan dengan adanya transformasi budaya dan dibuktikan dengan dekadensi moral. Seperti budaya kekerasan dan pornografi telah masuk ke dalam ruang keluarga melalui media cetak online. Selain itu, banjirnya informasi yang membutuhkan tenaga ketat dalam menyaringnya. Hal ini dengan kata lain saat ini telah memasuki era post-truth. Anak dibawa untuk percaya pada informasi-informasi media yang belum jelas keabsahannya. Alhasil informasi tersebut memancing daya imajin, daya keterhambatan perkembangan otak dan sebagainya. Walaupun tidak semua informasi menimbulkan dampak negatif, namun prosentase besar terletak pada dampak negatif daripada positif.

Munculnya era ini ditunjukkan dengan revolusi industri 4.0, hal ini justru menguatkan teknologi yang serba canggih. Saat ini anak-anak (pra-sekolah) tidak ada yang tidak mengenal dengan namanya gadget, smartphone, bahkan mereka lihai dalam mengoperasikannya. Berawal dari sinilah kecemasan para orang tua memuncak. Kekhawatiran kepada anak yang candu gadget akan 
merusak sistem perkembangan otak, psikomotorik, bahkan afektifnya. Untuk itu usaha mereka begitu kuat untuk mengalihkan gadget kepada mainan lain yang lebih manfaat baginya. Alhasil bagi mereka, media boneka itu menjadi salah satu solusi atas alasan-alasan tersebut.

Arus globalisaasi ini sadar ataupun tidak disadari memang mampu membuat perubahan dari segala aspek kehidupan. Perubahan ini tikak dapat dihindari akibat ilmu pengetahuan dan teknologi yang semakin canggih. Artinya penguasaan teknologi dan informasi harus dimiliki dalam setiap individu dan cerdas dalam menggunakannya itu jauh lebih penting (Madjid 2008, 72). Namun bukan berarti individu itu temasuk anak-anak yang belum saatnya. Teknologi dan informasi ini bukan terbatas pada gadget semata, namun saat ini telah hadir berbagai media-media teknologi yang luar biasa kehandalannya.

Prinsip para orang tua baru ini menghasilkan sebuah wawasan tentang betapa perlu penanganan khusus terhadap anak-anak dalam menghadapi era global, sehingga anak-anak diarahkan pada pendidikan berbasis teknologi. Secara teknologi, boneka tersebut memliki kelebihan dan yang menjadi problem ialah kemahalan dari boneka tersebut dan pastinya mengggunakan atas nama "agama". Di sinilah terjadi pergeseran makna memahami agama sehingga terkomodifikasi sedemikian rupa. Wajah orang tua baru saat ini ialah mereka yang berimajin pada kesalehan-kesalehan anaknya dengan didukung dengan simbolsimbol media atau bisa disebut dengan virtual religion yang dianggap praktis.

\section{E. Tantangan Pendidikan Islam}

Salah satu akibat dari globalisasi ialah dekadensi moral. Ini tantangan bagi pendidikan Islam, walaupu tidak hanya pendidikan Islam yang bertanggung jawab namun ini merupakan bagian terbesar peran pendidikan Islam, baik itu di keluarga, sekolah, maupun masyarakat. Hadirnya globalisasi menimbulkan paradoks bagi pendidikan Islam. Di satu sisi harus menghadapi, 
satu sisi Dalam kacamata pendidikan Islam, globalisasi menjadi sebuah paradoks. Bukan lagi kawan atau lawan namun sebagai dinamisator atau mesin. Pendidikan Islam menarik arus global yang sesuai bahkan dikembangakan, sementara yang tidak sesuai diulur, dilepas atau ditinggalkan (Assegaf 2004, 10). Tugas utama pendidikan Islam ialah menekankan para penanaman moral. Moral itu berangkat mulai dari pendidikan keluraga. Orang tua tempat sekolah yang utama, sehingga di sana telah dijelaskan bahwa bagi orang tua baru bertransformasi menjadi orang tua yang sesugguhnya. Bahkan proses globalisasi yang demikian cepat dan ditopang oleh perkembangan industri yang menuntut penemuan dan inovasi-inovasi baru bagi produk temuan teknologi untuk dipasarkan (Latifah 2017, 201). tuntutan kehadiran para ilmuan yang mempunyai kemampuan berpikir analitik dan saintstifik serta kemampuan riset dari yang sederhana ke yang kompleks dan kemampuan untuk terus berinovasi jelas memerlukan jawaban konkrit lembaga pendidikan Islam yang bermutu.

Tantangan Pendidikan Islam memasuki ranah ekonomi dan politik saat ini yang mempengaruhi bahkan menggeser konsep pendidikan Islam yang sesungguhnya. Pendidikan bukan lagi dipikul pada bahu sekolah, namun harus dikembalikan pada keluarga dan masyarakat. Artinya sekolah bukan satu-satunya jaminan. Pendapat Ki Hajar Dewantara tentang tripusat pendidikan perlu dibumikan kembali, yang mana saat ini perlahan luntur karena kesibukan para orang tua sehingga sekolah menjadi tempat awal dan akhir pendidikan (Taman Siswa 1962, 70). Bagi Sindhunata bahwa pengembalian pendidikan dan perlu ada sinergitas pendidikan dalam cakupan tripusat tersebut untuk memikil tanggung jawab secara bersama-sama, artinya pendidikan tak dapa tidak haus terkait dengan politik. Bahkan terus menjadi isu politik, sehingga perlu dibangun educational community. Pendidikan yang perlu komunikasi, kerjasama, dan partisipasi semua pihak (keluarga, sekolah, masyarakat, pengambil keputusan) untuk mendukung pelaksanaan pendidikan (Sindhunata 2003, 13). Bagi orang tua (konsumen boneka islami) tersebut cukup menghadirkan berbagai macam alat peraga seperti boneka hafiz 
tersebut untuk pendidikan agama bagi anak. Namun, problemnya orang tua seakan terlepas, pasrah dengan media tersebut dan produk-produk tersebut diperjualbelikan dengan harga yang tidak murah. Problem inilah yang kemudian perlu ada revitalisasi makna pendidikan Islam bagi keluarga (orang tua).

Model-model pendidikan dan pembelajaran seperti saat ini, tidak bisa untuk mengahadapi arus global dan perlu terus menerus melakukan inovasi. Pendidikan pada anak di dalam keluarga dimulai tidak hanya pembiasaan pada anak, biasa mengaji, biasa hal-hal yang sifatnya ubudiyah, namun anak membutuhkan 'model' untuk memperkuat pembiasaan tersebut. Model itu tidak lain ialah orang tua dan keluarga yang ada di rumah. Sebagaimana teori social learning Albert Bandura, bahwa anak sebenarnya diam-diam akan meniru orang tuanya. Untuk itu anak sebenarnya membutuhkan model yang terbaik untuk ditiru. Model itu tidak lain ialah orang-orang terdekatnya -orang tua dan keluarga (Bandura 1977). Penerapan teori Bandura ini akan mengendap dan menjadi habitus sampai ia dewasa. Teori Bourdieu tentang "habitus". Habitus adalah pembiasaan sikap yang dilakukan berulang-ulang atau membuat tindakan sosial menjadi biasa (natural) sehingga muncul kebiasaan yang terlembagakan oleh anggota masyarakat dan akhirnya membentuk sebuah identitas dan kelas sosial baru (Bourdieu 1977, 79). Pembiasaan berulang-ulang ini dilakukan secara sadar atau tidak sadar. Sesuai perjalanan waktu, pembiasaan ini, atau naturalisasi tindakan ini, akhirnya membentuk sebuah kultur baru dalam hal ini kultur kelas menengah, dalam waktu yang panjang karena individu atau aktor yang melakukan pembiasaan itu. Menurut Bourdieu juga bahwa transformasi habitus yang paling efektif ialah melalui teladan.

\section{F. Penutup}

Era global mampu mengubah cara pandang/ pola berpikir sesorang yang tidak bisa ditebak. Perubahan yang terus menerus yang mempengaruhinya, untuk itu konsep "A" tidak bisa dimaknai 
dengan pengertian yang telah baku, namun maksud itu akan terus berjalan sesuai kondisi zaman. Begitu juga orang tua saat ini khususnya orang tua muda yang baru memiliki anak telah memiliki pola berpikir yang berbeda yang menggeser konsep pendidikan Islam dan makna kesalehan. Bagi mereka kesalehan harus diperkuat dengan mainan-mainan edukasi islami yang mampu transformasi of knowledge pada anak walaupun mainan itu cukup mahal. Konsep seperti ini yang membuat wajah-wajah baru pada orang tua yang telah mewariskan virtual agama pada anak secara dini. Padahal perlu disadari bahwa pendidikan agama pada anak yang penting ialah penekanan pada model. Model terbaik yaitu orang tua dan yang harus diikuti itulah yang efektif. Dengan kata lain orang tua perlu menjadi teladan sepanjang hari bagi anakanak mereka. 


\section{DAFTAR PUSTAKA}

Assegaf, Abdurrahman. 2004. "Membangun Format Pendidikan Islam di Era Globalisasi." In Pendidikan Islam dan Tantangan Globalisasi: Buah Pikiran Seputar; Filsafat, Politik, Ekonomi, Sosial, dan Budaya. Edited by Imam Machali. Yogyakarta: PRESMA Fak. Tarbiyah dan Ar-Ruzz Media.

Bandura, Albert. 1977. Social Learning Theory. Englewood Cliffs, N.J.: Prentice Hall.

Bourdieu, Pierre. 1977. An Outline of a Theory of Practice. trans. Richard Nice. Cambridge: Cambridge University Press.

D. Morgan (ed.). 2008. Keywords in Religion, Media and Culture. London: Routledge.

Fakhruroji, Moch. 2014. "Agama dalam Pesan Pendek: Mediatisasi dan Komodifikasi Agama dalam SMS Tauhid", Ph.D Thesis. Yogyakarta: Pascasarjana UGM Program Studi Kajian Budaya dan Media.

Hoover, S. M. 2006. Religion in the Media Age. New York: Routledge.

Kitiarsa, Patana. 2008. Religious Commodification in Asia: Marketting Gods. New York: Routledge.

Madjid, Nurcholish. 2008. Islam, Kemodernan, dan Keindonesiaan. Bandung: Mizan.

Majlis Luhur Taman Siswa. 1962. Karya Ki Hajar Dewantara, Bagian Pertama: Pendidikan. Yogyakarta, Percetakan Taman Siswa.

Marshall, Sahlins. 1976. Culture and Practical Reason. Chicago: University Chicago Press.

Marx, Karl. 1976. Capital: A Critique of Political Economy. Vol 1. trans. Ben Fowkes. London: Penguin.

Mosco, Vincent. 1996. The Political Economy of Communication, Rethingking and Renewal. London: Sage Publication.

Mosco, Vincent. 2009. The Political Economy of Communication. Ed. 2. London. Thousand Oaks: Sage.

Sindhunata, 2003. "Pendahuluan." In Menggagas Paradigma Baru Pendidikan; Demokratisasi, Otonomi, Civil Society, Globalisasi. 
Yogyakarta: Kanisius.

Sinha, Vineeta. 2011. Religion and Commodification: Merchandizing Diasporic Hinduism. New York: Routledge.

Smith, Adam. 1976. An Inquiry into the Nature and Causes of the Wealth of Nations. Oxford: Clarendon Press.

Stiglitz, Joseph E. 2006. Making Globalization Work. New York: W.W. Norton.

Ward, Graham. "The Commodification of Religion, or the Consummination of Capitalism." In Theology and the Political: The New Debate. Edited by Creston Davis, Jhon Milbank, and Slavojiek. Durham: Duke University Press.

Wolf, Martin. 2004. Globalisasi: Jalan Menuju Kesejahteraan. Jakarta: Obor.

Budiyanto, A. 2009. "Playing with Piety: The Phenomenon of Indonesian Muslim Dolls." In Explorations: A Graduate Student Jurnal of Southeast Asian Studies 9.

Dunn, Rima dan Adam George Dunn. 2016. “Bad Dolls/ Reappropriating Badness: Performing the Feminine with Reference to Arab Muslim Dolls and Tiqqun's Young-Girl." JMEWS (Jurnal of Middle East Women's Studies).

Jati, Wasisto Raharjo. 2015. "Islam Populer sebagai Pencarian Identitas Muslim Kelas Menengah.” Teosofi: Jurnal Tasawuf dan Pemikiran Islam 5: 1.

Latifah, Nur. 2017. "Pendidikan Islam di Era Globalisasi." Palapa: Jurnal Studi Keislaman dan Ilmu Pendidikan 5: 1

Yusuf, Muhamad Fahrudin. 2016. "Komodifikasi: Cermin Retak Agama di Televisi: Perspektif Ekonomi Politik Media." INJECT (Interdisciplinary Journal of Communication) 1: 1. 